Jasper P. Sluijs, Commercial Divisions of Public ENTITIES AND the Limits of COMPETITION LAW,

Working Paper version 2.0, July 2019, j.sluijs@uu.nl

\title{
COMMERCIAL DIVISIONS OF PUBLIC ENTITIES AND THE LIMITS OF EU COMPETITION LAW
}

\author{
Dr. Jasper P. Sluijs*
}

\begin{abstract}
Competitive behavior by public entities is generally approached in the literature as concerning the traditional Stateowned enterprises pursuing public interest or political economy objectives. However, increasingly we see examples of commercial divisions of public entities aiming to generate revenue-think of a commercial branch of a forestry service selling timber to construction firms to supplement its tax-based revenues. Because these commercial divisions can enjoy competitive advantages over their private competitors, their behavior may distort competition and market entry. A survey of Member States demonstrates that commercial divisions of public entities have become prevalent throughout the EU, and member states tend to approach these potential anticompetitive effects through competition law(-related) frameworks.

This article points out, however, that a competition law framework may be ill-suited to address anticompetitive effects of commercial divisions of public entities. First, commercial divisions may not qualify as 'undertakings' under competition law to begin with. Second, the substantive application of arts. 102 and 106 TFEU to commercial divisions cannot be strongly established. Third, competition authorities may face procedural and institutional challenges when enforcing against commercial divisions of public entities.

While the designated competition law framework seems unable to address potential anticompetitive effects of commercial divisions of public entities, also an unequal playing field follows from the different treatment of private and public competitors in the application and enforcement of competition law. Moreover, the various competition lawinspired approaches towards commercial divisions of public entities throughout the EU can hamper the internal market. Because a modified and harmonized application of EU competition law to commercial divisions may not be practically feasible, regulation outside competition law could be more fitting. Before resorting to remedies, however, more research is necessary to appreciate and quantify the possible distortion of competition by commercial divisions of public entities, compile best-practice regulatory responses and further study effects on matters related to the rule of law.
\end{abstract}

JEL: D43, H44, K21, K42, L32, L33, L44

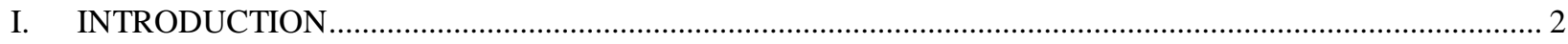

II. ON COMPETITIVE BEHAVIOR BY PUBLIC ENTITIES ………................................................... 2

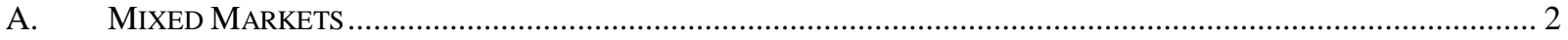

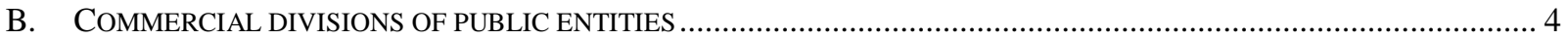

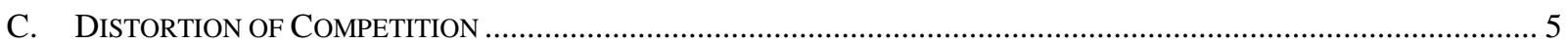

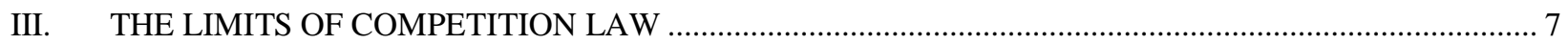

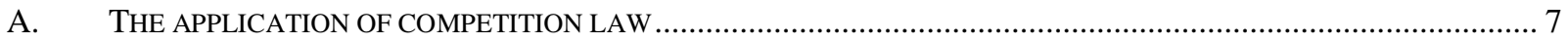

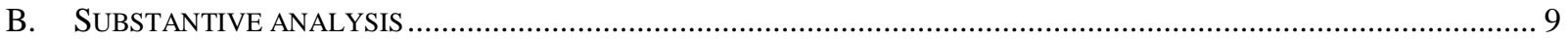

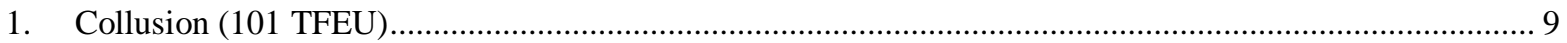

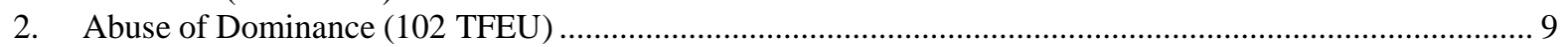

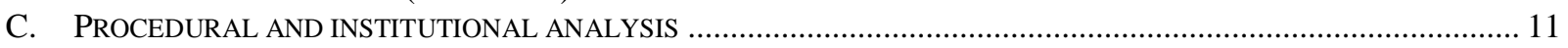

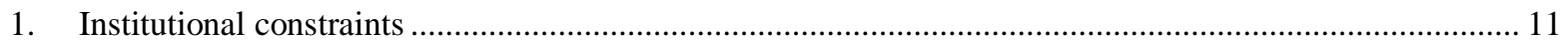

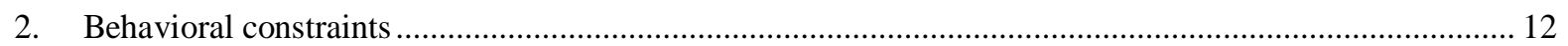

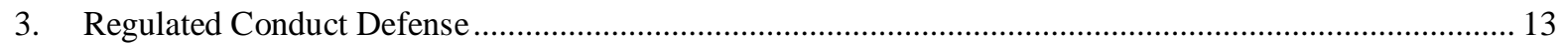

IV. CONSEQUENCES FOR COMPETITION AND THE INTERNAL MARKET ......................................... 14

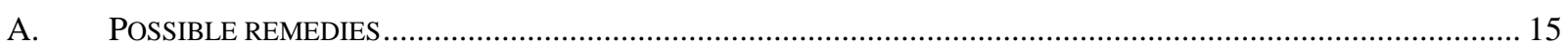

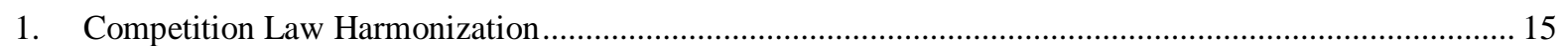

2. Regulatory harmonization beyond competition law ..................................................................... 16

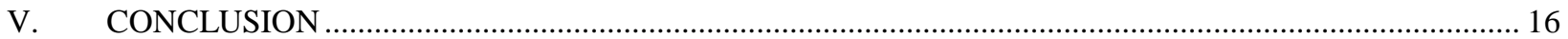

\footnotetext{
* Assistant professor, Utrecht University School of Law, j.sluijs@uu.nl. The author wishes to acknowledge Vladimir Bastidas, Paul de Bijl, Daan Boot, Linde Bremmer, Anna Gerbrandy, Agnieszka Janczuk-Gorywoda, Willem Janssen, Viktorija Morozovaite, Thibault Schrepel and scholars at TILEC, ASCOLA, and the Hungarian academy of sciences for helpful comments and suggestions during the various stages of researching and drafting this paper. Special thanks go out to the LLM students in my 'Government as a Competitor' clinic and thesis student Bart van Hemessen, together providing a small army of research assistants. No outside funding was received or relied upon for this paper.
} 


\section{INTRODUCTION}

Consider the following scenario: a national statistics agency produces statistics based on so-called microdata. These are 'raw' data at the level of (anonymized) individuals, companies and addresses that can be used as an intermediate product for research purposes. Under certain conditions firms, such as consultancies, can request access to microdata for analysis and interpretation.

At a certain point the statistics agency starts offering its own for-profit microdata analysis service, which operates in direct competition to the abovementioned consultancies. The statistics agency uses resources from its tax-funded budget to market its microdata analysis services, and allocates its civil servants to analyze microdata part time. Because the agency also has better access to microdata than its competitors, it can realize numerous efficiencies. This allows the agency to undercut the commercial rates of consultancies. Soon, microdata analysis generates a substantial amount of the statistics agency's budget.

The competing consultancies find themselves in a tough spot: they could express disagreement with the statistics agency, but also need the agency for access to microdata. Moreover, where could the consultancies go for a formal complaint and redress - and on what grounds?

Scenarios like the above have become more common in the EU since the financial crisis of the late 2000s. Increasingly public entities, notably agencies, have instantiated commercial divisions to raise additional revenue. These commercial divisions can enjoy competitive advantages over private competitors that raise questions about the appropriateness, if not lawfulness, of their practices. Various EU member states have responded to possible adverse effects on markets of commercial divisions by applying competition law, or by enacting supplementary laws based on competition law principles. The present article is the result of an exploratory study that documents the phenomenon of commercial divisions of public entities, analyzes its possible effects on competition and assesses how competition law relates to those effects.

The article proceeds in the following way. First, section II develops the phenomenon of commercial divisions of public entities by reviewing the economic literature on competition between public and private firms, before establishing commercial divisions as distinct from State-owned enterprises (SOEs). Numerous examples from various EU Member States are introduced, as well as legal responses to this phenomenon across Member States. Then, possible distortions of competition by commercial divisions are explored.

The following section III assesses the application of competition law to commercial divisions of public entities. The focus is on competition law, as many (if not all) EU Member States have enacted legal frameworks pertaining to commercial divisions of public entities that either utilize or build upon EU competition law. The possible application of competition law is analyzed on a substantive and procedural/institutional level.

Section IV, then, outlines the consequences of the current competition law-related approach to commercial divisions of public entities, and introduces possible remedies to problems associated with this competition law approach. The final section $\mathrm{V}$ discusses limitations of the present research, leading into an agenda for further research.

\section{ON COMPETITIVE BEHAVIOR BY PUBLIC ENTITIES}

This section first explores the ways in which public entities can compete on markets. It then proceeds to single out a hitherto under-studied manifestation of competitive conduct of public entities: commercial divisions of public entities. Finally, this section lays out the ways in which competitive conduct of these commercial divisions could affect competition.

\section{A. Mixed Markets}

In some markets private firms face competition from public entities. Typical examples mentioned in the literature are liberalized utility markets with (partially) state-owned incumbents, such as energy, railway and postal markets; markets with (recently) nationalized firms, such as banking; and markets related to the welfare state, such as 
healthcare, public housing and education. ${ }^{1}$ The key difference between a private firm and a public entity in these settings, is that the latter is unlikely to go bankrupt and is (partially) funded through taxes. ${ }^{2}$

Public entities can have various non-mutually exclusive motivations for competing in markets: maintaining public service obligations, for various reasons related to political economy, or to raise revenue. ${ }^{3}$ Table 1 below distinguishes these 3 motivations further. Note that competitive behavior by public entities can be by intention or as an (unintended) consequence: a public entity could intentionally compete with private firms to raise revenue, or effectively end up competing with private firms when maintaining public service obligations or pursuing political economy goals.

Table 1: examples of competition by public entities in markets

\begin{tabular}{cccc}
\hline $\begin{array}{c}\text { Motivation for } \\
\text { competitive behavior }\end{array}$ & Public service obligations & Political economy & Raising Revenue \\
Examples & $\begin{array}{c}\text { Providing health services, } \\
\text { transportation, energy, } \\
\text { housing, education, etc. to } \\
\text { citizens }\end{array}$ & $\begin{array}{c}\text { Advancing industrial } \\
\text { policy, protectionism, } \\
\text { safeguarding civil service } \\
\text { status of employees, etc. }\end{array}$ & $\begin{array}{c}\text { Trading goods or } \\
\text { services in addition to } \\
\text { tax-funded revenue }\end{array}$ \\
\hline
\end{tabular}

Markets with competition between public and private actors are referred to as 'mixed markets' in the economics literature. ${ }^{4}$ Theoretical research in industrial organization demonstrates that both in settings of mixed duopoly and mixed oligopoly, mixed markets can yield higher social welfare outcomes than purely private markets. ${ }^{5}$ However, firms' profits are lower in mixed oligopoly markets than in private oligopoly markets. ${ }^{6}$ Similarly, it has been demonstrated that in a mixed duopoly price competition is the dominant strategy equilibrium for the public and private firm, both in case of substitute and complimentary products between both firms. ${ }^{7}$ Such price competition would then lower profits for firms.

This industrial organization literature on mixed markets typically concerns the traditional State-owned enterprises (SOEs) pursuing public interest or political economy goals. ${ }^{8}$ Similarly, in law and economics scholarship a literature on competition law applied to SOEs has developed. ${ }^{9}$ Even though this form of State-ownership has progressively been rolled back in Europe by waves of liberalization and privatization, ${ }^{10}$ empirical research shows that SOEs are still a factor in European markets. ${ }^{11}$

Nevertheless, the OECD points out that a broad spectrum of commercial activities is performed by public entities beyond the realm of the traditional SOEs, with the aim of generating revenue. ${ }^{12}$ This would concern national or local

\footnotetext{
${ }^{1}$ de Fraja, Mixed Oligopoly: Old and New, in The Pros AND Cons of COMPETITION IN/By the Public SeCtOR 11-42 (2009).

${ }^{2}$ Arvid Fredenberg, Introduction, in THE PROS AND CONS OF COMPETITION IN/BY THE PuBlic SeCtor 8-11, 8 (Arvid Fredenberg ed., 2015), http://www.konkurrensverket.se/publications-and-decisions/the-pros-and-cons-of-competition-inby-the-public-sector/ (last visited Jun 13, 2018).

${ }^{3}$ OECD, Maintaining a level playing field between public and private business (2012).

${ }^{4}$ See, e.g. Tsuyoshi Shinozaki \& Minoru Kunizaki, Basic Properties of a Mixed Oligopoly Model, in The ThEORY OF MiXed Oligopoly: PRiVATIZATION, Transboundary ACtivities, AND THEIR APPLiCATIONS 3-13 (Mitsuyoshi Yanagihara \& Minoru Kunizaki eds., 2017).

${ }^{5}$ Stefan Lutz \& Mario Pezzino, Vertically Differentiated Mixed Oligopoly with Quality-dependent Fixed Costs, 82 THE MANCHESTER SCHOOL (2013); Xuan Nguyen, On the efficiency of private and state-owned enterprises in mixed markets, 50 ECONOMIC MODELLING 130-137 (2015).

${ }^{6}$ Nguyen, $i d$.

${ }^{7}$ See Toshihiro Matsumura \& Akira Ogawa, Price versus quantity in a mixed duopoly, 116 ECONOMICS LETTERS 174-177 (2012); But see Marcella Scrimitore, Price or quantity? The strategic choice of subsidized firms in a mixed duopoly, 118 ECONOMICS LETTERS 337-341 (2013) (demonstrating that in mixed duopoly with a subsidized public firm, competition on quality can be a dominant strategy equilibrium).

${ }^{8}$ See, e.g. Helmuth Cremer, Maurice Marchand \& Jacques-Francois Thisse, The Public Firm as an Instrument for Regulating an Oligopolistic Market $\dagger, 41$ OxFORD ECONOMIC PAPERS 283-301 (1989); Stefan Buehler \& Simon Wey, When Do State-Owned Firms Crowd Out Private Investment?, 14 JouRnAL OF INDUSTRY, COMPETITION AND TRADE 319-330 (2014); de Fraja \& Flavio Delbono, Alternative Strategies of a Public Enterprise in Oligopoly, 41 OXFORD ECONOMIC PAPERS 302-311 (1989); Nguyen, supra note 5; Hiroaki Ino \& Toshihiro Matsumura, What role should public enterprises play in free-entry markets?, 101 JOURNAL OF ECONOMICS 213-230 (2010); Matsumura and Ogawa, supra note 7.

${ }^{9}$ See, e.g., David E.M. Sappington \& J. Gregory Sidak, Competition Law for State-Owned Enterprises, 71 ANTITRUST L.J. $479-524$ (2003); David E. M. Sappington, J. Gregory Sidak \& John R. Lott, Are Public Enterprises the Only Credible Predators?, 67 THE UNIVERSITY OF CHICAGO LAW REVIEW 271-292 (2000); David E. M. Sappington \& J. Gregory Sidak, Incentives for Anticompetitive Behavior by Public Enterprises, 22 REVIEW OF INDUSTRIAL ORGANIZATION 183-206 (2003).

${ }^{10}$ Bellini, Nicola, The Decline of State-Owned Enterprise and the New Foundations of the State-Industry Relationship, in THE RISE AND FALL OF STATE-OWNED ENTERPRISE IN THE WESTERN WORLD 25-48 (Pier Angelo Toninelli ed., 2000).

${ }^{11}$ See Eleanor M. Fox \& Deborah Healey, When the State Harms Competition - The Role for Competition Law, 79 ANTITRUST LAW JouRNAL 769-820, 777-780 (2014).

${ }^{12}$ OECD, supra note 3 at 15 .
} 
governments and agencies involved in commercial activities alongside their public interest tasks. Such initiatives have the following characteristics: ${ }^{13}$

- The government charges for a service

- The government activity is commercial by nature

- There are no explicit restrictions on profitability

- There are actual or potential competitors

An additional difference with the traditional SOEs is the type of market on which revenue-seeking public entities are active. Whereas SOEs tend to be active on liberalized markets that traditionally have a large public presence, revenueseeking public entities are more common in otherwise purely private markets. ${ }^{14}$

These commercial activities are typically performed by divisions within a public entity. This competitive conduct by commercial divisions of public entities may currently outnumber SOE activity in Europe. ${ }^{15}$ While these commercial divisions of public entities have typically been instantiated to generate revenue, this tends not to be the sole aim of the divisions. Rather, aims of revenue generation often coincide with traditional government goals of equity and social welfare. ${ }^{16}$

Even though competitive conduct by non-SOEs seems a common phenomenon, the literature in industrial organization and law \& economics is still predominantly concerned with public interest or political economy pursuing SOEs when studying competitive conduct by public entities. ${ }^{17} \mathrm{It}$ is therefore that the present paper moves beyond the traditional SOEs, to focus rather on competitive behavior from within public entities. Because revenue generation as an explicit goal is the main difference between these commercial divisions and the traditional SOE, this difference will be highlighted in the subsequent analysis. This focus does not exclude the situation in which the commercial division (in)directly also contributes to the public interest.

\section{B. Commercial divisions of public entities}

This category of competitive behavior by public entities applies to unincorporated divisions within public organizations, often without their own legal personality. These divisions then pursue commercial activities beyond public interest tasks or political economy considerations, but rather to generate revenue primarily. Consider the following examples from a variety of EU member states: ${ }^{18}$

- In Denmark a commercial division of the ministry of foreign affairs offers paid language classes to citizens.

- In Finland divisions of government agencies provide commercial services in statistics, technical research and meteorology. Moreover, divisions of local governments commercially offer welfare services, operate power plants and run harbors.

- A division of the Polish forestry service provide commercial activities, for instance by selling timber.

- Also in Spain commercial divisions of government agencies compete with the private sector, for instance in digital certification.

- In the United Kingdom divisions of various departments of government commercially offer products and services, such as the Ordnance Survey.

- In France a number of government agencies contain divisions engaged in economic activities, such as the national meteorological institute and the national institute for archeological research.

- A number of Swedish non-incorporated divisions of government agencies are active in markets, for instance in construction and meteorological services. Moreover, local governments offer commercial services in markets as diverse as cleaning, vehicle rental, architecture and building maintenance. ${ }^{19}$

\footnotetext{
${ }^{13}$ Deborah Cope, Regulating Market Activities in the Public Sector: Background Note, 7 OECD JOURNAL OF COMPETITION LAW AND POLICY $31-$ 94, 50 (2004).

${ }^{14}$ Hans Friederiszick \& Jakub Kałużny, On the Difficult Relationship between Competition Policy and Public Enterprises: Lessons to be Learned from Recent Developments in the Field of European State Aid Control, in THE Pros AND CONS OF COMPETITION IN/By THE PUBLIC SECTOR 99162, 125 (Arvid Fredenberg ed., 2015), http://www.konkurrensverket.se/publications-and-decisions/the-pros-and-cons-of-competition-inby-thepublic-sector/ (last visited Jun 13, 2018).

${ }_{16}^{15}$ OECD, Competitive Neutrality in Competition Policy 5 (2015).

${ }^{16}$ OECD, A Compendium of OECD Recommendations, Guidelines and Best Practices bearing on Competitive Neutrality 26 (2012).

${ }^{17}$ Supra notes 8,9

${ }^{18}$ For an overview of OECD countries, see OECD, COMPETITIVE NEUTRALITY: NATIONAL PRACTICES 29-30 (2012).

${ }^{19}$ Swedish Competition Authority, WP3 Discussion on Corporate Governance, SOEs and Competitive Neutrality 3 (2009).
} 
Although not part of the aforementioned OECD survey, the Netherlands moreover offers a number of examples concerning commercial activities within government organizations. Its national statistics agency offers high-level statistical analysis of their data to clients, ${ }^{20}$ thus directly competing with private economic research firms who offer similar services. The Netherlands' forestry service commercially sells timber and biomass. Furthermore, the Netherlands' National Forensic Institute has been offering a number of commercial services, such as training of physicians and DNA lab research. The Dutch Chamber of Commerce commercially offers certification services for legal entities. Finally, the Land Registry Bureau of the Netherlands commercially sells aerial pictures, topographic prints and landscape analysis services. Furthermore, in local government a wide array of commercial activities is performed, ranging from construction waste container rental, to operating landscaping services, sports facilities, swimming pools and parking garages.

The proliferation of these commercial divisions of public entities throughout the EU could in some cases be attributed to budget cuts of national governments following the financial crisis of the late 2000s and early $2010 \mathrm{~s} .{ }^{21}$ Funding for many public entities was diminished as part of austerity measures, while public entities were encouraged to balance their budget by independently generating revenue. As local governments are limited and agencies generally unable to independently impose taxes, offering products and services on markets can be the most effective way to raise additional revenue for a public entity. Another possible motivation for public entities to employ commercial divisions is related to cross subsidies within governments. ${ }^{22}$ Public entities could generate additional revenue streams for central governments besides tax revenues. Revenue raising by public entities to cross-subsidize the central government may lead to perverse incentives against the organizations' public interest objectives, and could become a proxy for government corruption.

The subset of commercial divisions of public entities that is the focus of the present research thus is particular in two ways. First, this kind of competitive behavior by public entities takes place outside of the realm of the traditional SOEs, by commercial divisions typically without a separate legal personality. Second, the competitive behavior of these commercial divisions mainly aims to generate revenue, and is typically not primarily driven by public interest or political economy considerations.

\section{Distortion of Competition}

Now that commercial divisions have been established as a distinct, prevalent, yet little studied manifestation of competitive conduct by public entities, it becomes opportune to address the possible effects on market mechanisms of these commercial divisions.

In general, commercial divisions of public entities can enjoy a number of competitive advantages over private sector rivals. Public entities generally face lower capital costs, are protected against hostile takeovers and bankruptcy, can have better access to (regulatory) information and infrastructure, can enjoy favoritism in public procurement, and could benefit from (tax funded) cross-subsidies ${ }^{23}$ At the same time, traditional competitive disadvantages associated with the inefficiency of the public sector could also apply to commercial divisions of public entities, including restrictive labor practices, bureaucracy, weak management and public service obligations. ${ }^{24}$ The literature is unclear on whether, and in what way, these competitive (dis)advantages relate to each other. It its therefore possible that the balance between competitive advantages and disadvantages of commercial divisions of public entities leads to an overall more or less efficient production process compared to private competitors, who can suffer from their own potential inefficiencies in production. ${ }^{25}$

Irrespective of their (relative) efficiency, the activity of commercial divisions on markets can have an effect on actual or latent competition on markets. First, the presence of public entities can affect actual competition in markets. De Fraja demonstrates that a public competitor will pursue maximization of total welfare and thus increase output of its products or services accordingly. The public competitor consequently would raise output higher than a private competitor would, leaving less residual demand for these private competitors. Confronted with this raise in output by

\footnotetext{
${ }^{20}$ Clients other than other governments to inform policy or law making

${ }^{21}$ OECD, supra note 3 at 21.

${ }^{22}$ Muiris MacCarthaigh, Managing state-owned enterprises in an age of crisis: an analysis of Irish experience, 32 POLICY STUDIES 215-230 (2011).

${ }^{23}$ OECD, supra note 15 at 7, 25. For more background on favoritism between public entities in public procurement procedures, see WILLEM Janssen, Eu Public Procurement LaW \& Self-Organisation: A Nexus of Tensions \& ReconCiliations 123-136 (2018).

${ }^{24}$ OECD, supra note 16 at 7.

${ }^{25}$ de Fraja, supra note 1 at $16-17$.
} 
the public competitor, the private competitor will consequently lower its output, and the producer surplus of the private competitor diminishes. ${ }^{26}$ Ultimately, this mechanism could drive private competitors out of the mixed market altogether, ${ }^{27}$ possibly by as a consequence of predation by the public firm. ${ }^{28}$

Second, competitive behavior of public entities on markets can affect latent competition by hampering entry. The mere presence of a public competitor on a market can amount to entry barriers for potential competitors because of the (perceived) competitive advantages public entities enjoy. ${ }^{29}$ This rationale seems to be premised on a broad definition of entry barriers ${ }^{30}$ over which economists have argued a lot. ${ }^{31}$ McAfee et al. have since provided a helpful distinction between an economic and an antitrust barrier to entry- the former referring to a cost incurred by entrants but not by incumbents, while the latter refers to a cost of delayed entry relative to immediate, but equally costly entry, thus reducing social welfare. ${ }^{32}$ The rationale that the competitive advantages of public entities in a mixed market amount to entry barriers seems to be premised on the concept of antitrust barriers to entry. A market with public firms may still be contestable for entrants, particularly given the above-mentioned competitive disadvantages of public firms. However, the competitive advantages of public firms can delay entry and thereby negatively affect social welfare.

The (static) welfare effects of driving out mechanism or entry barriers in these settings can be positive: because the foreclosing, entry deterring firm is public, monopoly prices will remain low. DeFraja, however, remarks that these positive welfare effects are premised on circular reasoning: because (and only if) the public firm in a mixed oligopoly pursues total welfare, will its monopolization yield positive effects on total welfare. ${ }^{33}$ Indeed, much of the economic literature on mixed oligopoly is premised on the public firm's incentive to pursue total welfare ${ }^{34}$ For commercial subsidiaries of public entities, however, at the very least total welfare is no longer their only aim. After all, these commercial subsidiaries are at least partially driven by revenue maximization. There is some proof in the literature of how an objective function of a public firm combining profit maximization and public interest concerns leads to predation with negative effects on welfare. ${ }^{35}$

In terms of dynamic competition, both foreclosing private competitors and hampering market entry of private competitors by commercial divisions of public entities could negatively affect innovation. ${ }^{36}$ Consequently, better and more efficient production of goods and services would not be brought to the market, ${ }^{37}$ with a negative effect on welfare in the long run.

It should be mentioned at this point that mixed markets could also yield more efficient outcomes than purely private markets, whereby the existence of public firms would have procompetitive effects. The economics literature has mentioned, for instance, that social ${ }^{38}$ or total ${ }^{39}$ welfare can be enhanced by the presence of a public firm on a market. Recall, however, that the models on which these papers are based tend to model the public firm as solely pursuing social welfare. ${ }^{40}$

${ }^{26} \mathrm{Id}$. at 19 .

${ }^{27}$ Swedish Competition Authority, supra note 19 at 2.

${ }^{28}$ John R. Lott, Predation by public enterprises, 43 JOURNAL OF PUBLIC ECONOMICS 237-251 (1990).

${ }^{29}$ Fredenberg, supra note 2 at 8; SWEDISH COMPETITION AUTHORITY, supra note 19 at 2; OECD, supra note 15 at 13.

${ }^{30}$ This broad definition is ultimately based on the work of Joe Bain, who defined entry barriers as any factor allowing abnormal profits of an incumbent firm without attracting entry. See JOE S. BAIN, BARRIERS TO NEW COMPETITION: THEIR CHARACTER AND CONSEQUENCES IN MANUFACTURING INDUSTRIES (1956).

${ }^{31}$ See, e.g. Dennis W Carlton, Why Barriers to Entry Are Barriers to Understanding, 945 (2004).

${ }^{32}$ R Preston Mcafee, Hugo M Mialon \& Michael A Williams, What Is a Barrier to Entry?, 94 AEA PAPERS \& ProceEDINGS 5, 463 (2004).

${ }^{33}$ de Fraja, supra note 1 at 20.

${ }^{34}$ See, e.g. Cremer, Marchand, and Thisse, supra note 8; Kenneth Fjell \& John S. Heywood, Mixed oligopoly, subsidization and the order of firm's moves: the relevance of privatization, 83 ECONOMICS LETTERS 411-416 (2004); Lutz and Pezzino, supra note 5; Nguyen, supra note 5; Corrado Benassi, Alessandra Chirco \& Caterina Colombo, Mixed spatial duopoly, consumers' distribution and efficiency, 156 ECONOMICS LETTERS 74-77 (2017).

${ }^{35}$ Sappington and Sidak, supra note 9.

${ }^{36}$ Daniel Sokol, What Role for Government Ownership in Business and What is the Best Form of Oversight?, in THE PROS AND CONS OF COMPETITION IN/BY THE PUBLIC SECTOR 44-98, 61 (Arvid Fredenberg ed., 2015), http://www.konkurrensverket.se/publications-and-decisions/thepros-and-cons-of-competition-inby-the-public-sector/.

${ }^{37}$ Office of Fair Trading, Competition in Mixed Markets 14 (2010).

${ }^{38}$ Nguyen, supra note 5; Lutz and Pezzino, supra note 5.

${ }^{39}$ Cremer, Marchand, and Thisse, supra note 8.

${ }^{40}$ Supra note 34 
Beyond effects on competitors, there are additional potential effects associated with competitive conduct by commercial divisions of public entities. The presence of public competitors in an otherwise private market could lead to an inefficient redistribution between buyers and tax payers, as the buyers of the goods and services provided by a public entity may receive a discount on its real cost, subsidized by tax revenue. ${ }^{41}$ More broadly, competitive behavior of public entities potentially blurs boundaries between public and non-public interest tasks of governments. Such blurred boundaries undermine the supposed impartiality of government and ultimately the rule of law. ${ }^{42}$ Raising revenue through competitive endeavors could incentivize government corruption and cronyism.

\section{THE LIMITS OF COMPETITION LAW}

As has been demonstrated above, competitive conduct by commercial divisions of public entities can raise distortions of actual or latent competition in markets. Many EU jurisdictions that recognize these actual or potential distortive effects on markets by public competitors, have instantiated corrective legal frameworks based on competition law principles. ${ }^{43}$ In some countries, notably the United Kingdom, competition law in and of itself has been applied towards public entities with some regularity. ${ }^{44}$ Other Member States have added on to their competition acts provisions pertaining to competitive behavior of public entities. For instance, Sweden has enacted a law stipulating that cases can be brought against a public entity offering goods or services when allegedly distorting or impeding competition by object or effect. ${ }^{45}$ Similar laws have been enacted in Finland and Denmark. In the Netherlands a chapter has been added to the competition act regulating economic activity by public entities, requiring such entities to charge prices equal to marginal cost and operate under functional separation, while prohibiting favoritism or sustaining information advantages over private competitors. ${ }^{46}$ This reliance in competition law or competition law principles throughout the EU warrants a substantive analysis of the application of this fields of law to commercial divisions of public entities. ${ }^{47}$

\section{A. The application of competition law}

It has been long established in the case law of the European courts that any "undertaking" falls under the ambit of EU competition law, irrespective of its legal personality. ${ }^{48}$ The defining characteristic of an undertaking is engagement in "economic activity," which comprises the offering of goods or services on a given market. ${ }^{49}$ Competition law would therefore generally apply to a public entity offering goods or services. Note that this applies even when - in case of (unincorporated) commercial divisions - the entity performing economic activity has no distinct legal personality as part of a government. ${ }^{50}$

A string of CJEU cases has further refined the extent to which commercial activities by public entities constitute economic activity. The court advanced a factual, case-by-case approach to determine whether or not a public entity could be engaged in economic activity. ${ }^{51}$ This case-by-case approach has factored in if the activity was also performed

${ }^{41}$ OECD, supra note 15 at 4 Please note that inefficient welfare distributions can also occur in purely private markets, for instance between consumers and investors.

${ }^{42} I d$. at 4.

${ }^{43}$ OECD, supra note 18 at 5.

${ }^{44}$ See, e.g. Bettercare Group Ltd v The Director General of Fair Trading (2001) CAT 6; London Borough of Newham v Khatun \& Ors (2004) EWCA Civ 55

${ }^{45}$ SwEDISH COMPETITION AUTHORITY, Utvärdering av reglerna om konkurrensbegräsende offentlig säljverksamhet (English summary) (2016).

${ }^{46}$ See chapter $4 \mathrm{~b}$ of the Netherlands Competition Act. For an example of practical application, see Autoriteit consument en markt, Unfair competition between government organizations and private businesses is not allowed (2014), https://www.acm.nl/en/publications/publication/13172/Unfair-competition-between-government-organizations-and-private-businesses-is-notallowed (last visited Jul 17, 2019).

${ }^{47}$ For reasons of scope this research does not concern the broader field of competition policy, which would have included state-aid law. Research on the application of state-aid law to commercial divisions of public entities would certainly be pertinent, yet more appropriate in a separate study. For a more detailed analysis in the relation between competition law and state-aid law in the EU, see Herwig Hofmann, Administrative Governance in State Aid Policy, in EU Administrative GovernanCE (Herwig Hofmann \& Alexander Türk eds., 2006).

${ }^{48}$ Höfner and Elser v. Macrotron, Case C-41/90, [1991] ECR I-1979, \$21 ("in the context of competition law ... the concept of an undertaking encompasses every entity engaged in an economic activity, regardless of the legal status of the entity and the way in which it is financed"). See also Poucet \& Pistre v. Assurances Générales de France, Joined cases C-159-60/91, [1993], ECR I-637 §17; Pavlov v. Stichting Pensioenfonds Medische Specialisten, joined cases C-180-84/98 [2000] ECR I6451, §74.

${ }^{49}$ Commission v. Italy, Case C-35/96 [1998] ECR I-3851, §36; FENIN v. Commission Case C-205/03 [2006], ECR I-6295, §25. Note that the European Courts have deemed the (not) for-profit status of an entity immaterial in this respect, see Fédération Française des Sociétés d'Assurance, and others v. Ministère de l'Agriculture et de la Pêche, Case C-244/94 [1995], ECR I-0401 and Pavlov, supra note 48, at \$110-119

${ }^{50}$ Commission Decision 90/456/EEC (Spanish International Express Courier Services), 1990 O.J. L. 233/19, Compass-Datenbank GmbH v Austria, Case C-138/11 [2012] ECLI:EU:C:2012:449, §35

${ }^{51}$ Erik Kloosterhuis, Defining non-economic activities in competition law, 13 EUROPEAN COMPETITION JOURNAL 117-149, 123 (2017). 
by private firms competing with each other, ${ }^{52}$ if the activity is provided for renumeration, ${ }^{53}$ and whether the public entity bears financial risk in its endeavor. ${ }^{54}$

For the purposes of this research, when determining if a commercial division of a public entity performs economic activity, it is crucial whether or not the entity offers goods and services as a part of exercising its public powers. To determine this, the courts can consider the aim of activities, their nature and the rules to which they are subject. ${ }^{55}$ Whether or not the activity by the public entity is provided for remuneration has not been deemed decisive by the ECJ ${ }^{56}$ Rather, offering goods and services by a public entity constitutes economic activity when it can be separated from the exercise of public powers. ${ }^{57}$ What actually constitutes a separate activity from the exercise of public power has not been defined clearly by the ECJ, yet it appears the Court looks for a "close link" between the contested activity and the public power entrusted to an entity. ${ }^{58}$ An activity need not be indispensable or essential to the public power of the entity in question - also optional or non-mandatory activities by public entities may be considered inseparable from the exercise of an organizations' public power. ${ }^{59}$

Therefore, competition law would apply to commercial divisions of public entities inasmuch as the commercial activities of these divisions can be separated from the exercise of public power according to the ECJ standard. Concerning many of the examples mentioned in section II-B above, this would be a matter for debate. A case could be made both ways whether or not, for instance, commercial logging can be separated from the public power of a national forestry service. Similarly, it would have to be determined to what extent a national statistics agency's statutory task of producing statistics can be considered separate from the analysis or interpretation of statistics by the agency for commercial purposes.

Of additional relevance to the application of the concept of "undertaking" is art. 106(2) TFEU. This article states that undertakings performing Services of General Economic Interest (SGEI) or being revenue-producing (State) monopolies are only subject to the rules of the EU treaties, particularly competition law provisions, insofar as "the application of such rules does not obstruct the performance, in law or in fact, of the particular tasks assigned to them." The concept of SGEI is complex and has been established through a myriad of CJEU cases $^{60}$ and Commission

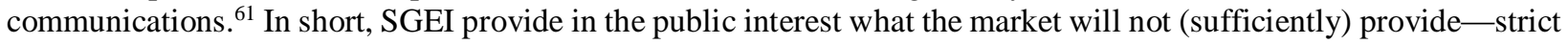
competition law enforcement would indeed be ill-suited under such circumstances. Another array of cases has been developed on what exactly constitutes an obstruction of the SGEI's assigned tasks by competition law provisions. ${ }^{62}$

It should be noted at this point that the concepts of SGEI and revenue-producing monopoly may very well apply to the traditional SOEs competing on (often liberalized) markets, for instance in utilities, transportation or (social) housing. The commercial divisions of public entities that the present research focuses on, however, are different from SOEs and will likely not be considered an SGEI or revenue-producing State monopoly. This is because the commercial divisions typically are not entrusted with a public interest task in absence of private alternatives in a market, but rather pursue revenue generation irrespective of private alternatives. As explained in above, ${ }^{63}$ commercial divisions of public entities tend to be active on otherwise private markets, rather than the liberalized markets with a traditional large presence of public firms. The examples of commercial divisions mentioned above in section II-B typically concern

\footnotetext{
${ }^{52}$ Firma Ambulanz Glöckner v Landkreis Südwestpfalz. case C-475/99 [2001] ECLI:EU:C:2001:577, §20; Ministero dello Sviluppo Economico v. Organismo di Attestazione SpA, Case C-327/ 12 [2013] ECLI:EU:C:2013:827, §35

${ }^{53}$ See, e.g. Commission v. Italy, Case C-35/96 [1998] ECLI:EU:C:1998:303, §37; Wouters et al. v. Nederlandse Orde van Advocaten [2002] EU:C:2002:98, §48; OTOC v. Autoridade da Concorrencia, Case C-1/12 [2013] ECLI:EU:C:2013:127, §37

${ }_{54}^{54}$ Commission v. Italy, supra note 53, at §37; Ministero dello Sviluppo economic, supra note 52, at §17; Poucet \& Pistre, supra note 48, at $\$ 12$

${ }_{55}^{55}$ SAT Fluggesellschaft v. Eurocontrol, Case C-364/92 [1994] ECR I-00043, §19-30

${ }^{56}$ See SAT Fluggesellschaft, id., at §28-30 and Diego Cali , Case C-343/95 [1997] ECR I-1547, §22-25

${ }^{57}$ See SELEX v. Commission, Case C-113/07 P, ECR I-02207, §72-77 Compass-Datenbank, supra note 50, §38

${ }^{58}$ SELEX, id., at $\$ 76$

${ }^{59} \mathrm{Id}$., at $\$ 79$

${ }^{60}$ For an expansive summary of the relevant case law, see Alison JONES \& BRENDA SuFRIN, EU COMPETITION LAW: TEXT, CASES, AND MATERIALS 629 (6 edition ed. 2016).

${ }^{61}$ The latest one being: Communication from the Commission to Parliament, Council, etc.: a Quality Framework for Services of General Interest in Europe, $\operatorname{COM(2011)} 900$ final, at 3 ("SGEI are economic activities which deliver outcomes in the overall public good that would not be supplied (or would be supplied under different conditions in terms of quality, safety, affordability, equal treatment or universal access) by the market without public intervention.")

${ }^{62}$ See JONES AND SUFRIN, supra note 62 at 633-642 for an overview of the development in ECJ cases.

${ }^{63}$ See supra section II-A
} 
non-essential activities, ancillary to or resulting from public interest tasks. SGEIs, conversely, follow from situations in which "certain obligations are imposed on [an undertaking] by the State in the general economic interest." ${ }^{4}$

So far this paper has established that a number of EU jurisdictions approach competitive conduct of public entities by means of competition law-including competitive conduct by commercial divisions of public entities. Furthermore, it has been outlined that commercial divisions of public entities would not automatically fall under the ambit of EU competition law. Even though the concepts of "undertaking" and "economic activity" have generally been defined broadly by the Courts, the economic activity of a public entity has to be separate from its exercise of public power to be considered subject to competition law. Whether or not this separation can be established would have to be determined on a case-by-case basis.

Given this case-by-case basis, it can be assumed that some activities of commercial divisions of public entities would fall under the ambit of competition law, whereas others would not. Concerning the activities that would be considered separate from the exercise of public power, the next step, then, would be to analyze how competition law would apply to these commercial divisions of public entities.

\section{B. Substantive analysis}

This paragraph covers the application of substantive EU competition law when applied to commercial divisions of public entities.

\section{Collusion (101 TFEU)}

It would be possible for a commercial division to form a cartel with direct competitors. Examples in and outside of the EU have long been reported in which public entities participated in private or export cartels, sometimes even as ring leaders. ${ }^{65}$ Fox \& Healey mention enforcement against SOEs for initiating cartels in milk production and postage in Spain. ${ }^{66}$ Cartel cases have been (unsuccessfully) brought against the public Canadian Crown corporations since the 1980s ${ }^{67}$ Moreover, the presence of a public sector competitor might incentivize the private actors on a given market to collude. ${ }^{68}$

It thus seems that in the circumstances that competition law applies to a commercial division of a public entity, art. 101 TFEU could be invoked when this commercial division allegedly participated in collusive agreements. In this case the Commission, a national competition authority or a private claimant could argue that such an agreement would fall under the scope of art. 101(1) TFEU, which prohibits agreements or concerted practices that may affect trade between member states by undertakings with the object or effect of preventing, restricting or distorting competition on the internal market. Subsequently, it would have to be determined if the cumulative conditions of art. 101(3) TFEU would constitute an exception to the prohibition of art. 101(1).

It should be noted at this point, however, that the participation in a cartel by a commercial division of a public entity does not relate to the distortion of competition that was outlined in section II-C above. The negative effects on static or dynamic competition caused by foreclosure or entry deterrence mentioned here concern unilateral conduct by the commercial division, and collusion as a concept relies on multilateral conduct by a number of firms. ${ }^{69}$

Therefore, while the application of art. 101 TFEU to commercial divisions of public entities is possible substantively, this research will further investigate the relation between the observed potentially anticompetitive effects of commercial divisions of public entities and competition law provisions focused on unilateral conduct.

\section{Abuse of Dominance (102 TFEU)}

\footnotetext{
${ }^{64}$ Chemische Afvalstoffen Dusseldorp BV and Others v Minister van Volkshuisvesting, Ruimtelijke Ordening en Milieubeheer, Case C-203/96 [1998] ECLI:EU:C:1998:316, Jacobs AG, §103

${ }^{65}$ Raymond Vernon, Uncertainty in the Resource Industries: The Special Role of State-owned Enterprises, in RISK AND THE POLITICAL ECONOMY of RESOURCE DeVElopMEnT 207-223 (David W. Pearce, Horst Siebert, \& Ingo Walter eds., 1984).

${ }^{66}$ Fox and Healey, supra note 11 at 779.

${ }^{67}$ See, e.g. R. v. Eldorado Nuclear Ltd., 1 [1983] 2 S.C.R. 551; R. v. Uranium Canada Ltd.,[1983] 2 S.C.R. 55; Industrial Milk Producers Assn. v. British Columbia Milk Board, 5 [1989] 1 FC 463; Hughes v. Liquor Control Board of Ontario, [2018] ONSC 1723 (CanLII)

${ }^{68}$ Giovanni de Fraja \& Flavio Delbono, Game Theoretic Models of Mixed Oligopoly, 4 JouRnAL OF ECONOMIC SURVEYs 1-17 (1990); Stefano Colombo, Mixed oligopolies and collusion, 118 JOURNAL OF ECONOMICS 167-184 (2016).

${ }^{69}$ Hans Friederiszick \& Frank Maier-Rigaud, The Role of Economics in Cartel Detection in Europe, in THE MORE ECONOMIC APPROACH TO EUROPEAN COMPETITION LAW 179-196, 180 (Dieter Schmidtchen, Max Albert, \& Stefan Voigt eds., 2007).
} 
There is a strong body of EU case law on abuse of dominance of (former) SOEs, particularly in network industries. ${ }^{70}$ A variety of hypothetical examples can be construed in which a commercial division, deliberately or effectively, abuses a dominant position. For instance, when the subsidiary lowers prices to enhance social welfare or because of sheer limitless cross-subsidies, this could amount to predatory pricing for its competitors. Some anecdotal evidence of such practices has been documented..$^{71}$

Alternatively, when a commercial division competes with private firms downstream, an essential facility upstream supplied by the 'parent' public entity could be leveraged for discriminatory purposes, refusal to supply or a margin squeeze. ${ }^{72}$ This could happen when, for instance, a statistics bureau would selectively grant access to unedited statistical data to data analytics firms, and at the same time operate a commercial division that would offer data analysis services in direct competition with those firms.

However, for the abuse of dominance of commercial divisions of public entities to be established, actual market dominance would have to be demonstrated first. Dominance is generally defined as the ability for a firm to behave independently of competitors, customers or consumers, thereby preventing effective competition. ${ }^{73}$ Effectively, this amounts to independently raising prices, lowering output or negatively influencing innovation or quality. ${ }^{74}$ Dominance is established on a case-by-case basis, and involves a two-pronged test in which, first, the relevant (product and geographic) market is defined.$^{75}$ Second, the degree of market power is established based on market shares ${ }^{76}$ entry barriers $^{77}$ and countervailing buying power. ${ }^{78}$

Given the considerable variety of commercial divisions of public entities, and the various markets on which they are active, no overall conclusions can be drawn on their degree of market dominance. Dependent on the particular market definition, it would however be possible for some of these commercial divisions to hold a market share of $40 \%$ or more, which is the Commission's lower limit for market power. ${ }^{79}$ Moreover, as has already been established above, various competitive advantages that public entities enjoy could amount to entry barriers for the private competitors of the commercial divisions.

At the same time, anecdotal evidence suggests that market definition might be steep hurdle to take for public competitors in abuse of dominance cases. The Swedish competition authority mentions that Swedish courts have been reluctant to accept market definitions and accompanying market shares of public competitors in proceedings, and that several cases consequently have not proceeded to the assessment of competitive restrictions. ${ }^{80}$

Moreover, it is not altogether clear to what extent abuse of dominance by a commercial division of a public entity would have the same negative effects on consumer welfare as when perpetrated by a private firm. The Commission's 2009 guidance paper has elaborated on the term "anticompetitive foreclosure" to explain the relation between abuse of dominance and consumer welfare. The abusive conduct should negatively affect consumers "whether in the form of higher price levels than would have otherwise prevailed or in some other form such as limiting quality or reducing consumer choice." 81

\footnotetext{
${ }^{70}$ See France Télécom v. Commission, Case C-202/07 [2009] ECR I-2369 and Post Danmark v. Konkurrencerådt, Case C-209/10 [2012] EU:C:2012:172 (pretatory pricing); Deutsche Telekom v. Commission, Case C-280/08 [2010], ECR I-955 and Konkurrentsverket v. Teliasonera, Case C-52/09 [2011], ECR I-527 (margin squeeze).

${ }^{71}$ Cope mentions an example from Australia, in which the national meteorological institute lowered its prices for newspapers to zero upon entry of a new firm providing enhanced graphical material for the daily weather pages. See Cope, supra note 13 at 40.

${ }^{72}$ Even though it is unlikely for a commercial division downstream to concoct a margin squeeze together with its upstream (public) supplier, the cost advantages that the commercial division enjoys over competitors could amount to what in practice would be a margin squeeze.

${ }^{73}$ See United Brands v Commission, Case 27/76 [1978] ECR 207, at §65; Hoffmann-La Roche \& Co. v Commission, Case 85/76 [1979] ECR 461, at $\$ 38$. See generally Commission Communication, Guidance on the Commission's enforcement priorities in applying Article 82 of the EC Treaty to abusive exclusionary conduct by dominant undertakings, 2009 OJ C. $45 / 7$, at $\S 10$

${ }^{74}$ See Commission Communication, id., at $\$ 11$

${ }^{75}$ See United Brands v. Commission, Case 27/76 [1978] ECR 207, at \$19-35; Michelin v. Commission, Case 322/81 [1983] ECR 3461, at \$23-28, 37-45; Hilti v. Commission, Case T-30/89 [1991] ECR II-439, at §66-68; British Airways v. Commission, Case T-219/99 [2003] ECRII-5917, at $\S 110-116$

${ }^{76}$ Hoffmann-La Roche, supra note 73, at \$39-41; British Airways, id, at \$212-225

${ }^{77}$ United Brands, supra note 75, at $§ 121-129$, Michelin, supra note 75, at $\$ 53-61$

${ }^{78}$ Commission Decision COMP/E-1/38.113 (Prokent/Tomra) 2006, OJ C. 219/11, at $\$ 89$

${ }^{79}$ Commission Communication, supra note 73 , at $\$ 14$

${ }^{80}$ See Swedish Competition Authority, supra note 47 at 10.

${ }^{81}$ Commission Communication supra note 73 , at $\$ 19$. Please note that the conception of "consumer" in consumer welfare is, at best, ambiguous. See Pinar Akman, "Consumer" versus "Customer": The Devil in the Detail, 37 JOURnAl OF LAW AND SOCIETY 315-344 (2010).
} 
As has been pointed out above in section II-A, even when public entities are active on markets with the express aim of generating revenue, traditional social welfare objectives of the public sector may still influence their behavior on markets. ${ }^{82}$ Therefore, when commercial divisions of public entities also pursue social welfare when offering their goods or services, it would be highly unlikely for prices to be raised by a dominant firm after having forced (private) competitors out of the market by sub-competitive pricing. After all, the commercial division will keep prices low for consumers to maximize social welfare, also after foreclosure. When a commercial division offers goods or services with the aim of raising revenue for itself or the central government, it would become more likely to raise prices post foreclosure. If this latter scenario were to occur, the as-efficient-competitor test outlined by the Commission ${ }^{83}$ would likely be met. Given the general inefficiency of the public sector as compared to the private sector (see section II-B), it would be probable that in these circumstances competition is hampered with (private) firms considered as efficient as the dominant commercial division. ${ }^{84}$

In any event, it has been pointed out in the literature that a focus on short-term (static) pricing effects has been a decisive factor in enforcement of abuse of dominance cases. However, the more long-term aspects of quality and consumer choice need to be factored in as well. ${ }^{85}$ Even if a commercial division were to keep prices low after (effectively) forcing private competitors out of the market, consumer welfare could still be affected negatively. In absence of competitive pressure post foreclosure product innovation could be hampered, and consumers would generally have fewer products or services to choose from.

Based on the above, it would be possible in principle to establish market dominance of a commercial division of a public entity, and to determine abuse of such a dominant position. Because of both the various case-specific factors in the abuse of dominance case law, and the variety in which commercial divisions can operate, little can be said at this point about the possible outcome of such cases before the European Commission and courts, or national competition authorities and national courts. Anecdotal evidence from Sweden suggests that market definition might be problematic in such proceedings. Moreover, commercial divisions that operate to enhance social welfare are less likely to abuse a dominant position than commercial divisions aiming to generate revenue per-se.

\section{Procedural and institutional analysis}

The European Commission tends to focus on the large abuse of dominance cases with an appreciable effect on the Internal Market at large. ${ }^{86}$ Consequently, it would be unlikely for the Commission to bring proceedings against commercial divisions of public entities, who would typically impact markets on a national level. National competition authorities, however, would be more inclined to bring proceedings. For instance, in France the Competition Authority has established a somewhat of a track record on competitive conduct by public entities. ${ }^{87}$

Were a competition authority to bring proceedings, commitment decisions or fines could be issued to commercial divisions found to be abusing a dominant position in a market. This decision could then be appealed before the National and eventually European courts. There would, however, be procedural aspects complicating this process.

\section{Institutional constraints}

\footnotetext{
${ }^{82}$ OECD, supra note 16 at 26.

${ }^{83}$ Commission Communication, supra note 73 , at $\$ 23$

${ }^{84}$ With its landmark ruling in the Intel case, and by reversing a GC ruling, the CJEU has affirmed the standard of Post Danmark 1 (supra note 70) claiming that "it must be borne in mind that it is in no way the purpose of Article 102 TFEU to prevent an undertaking from acquiring, on its own merits, the dominant position on a market. Nor does that provision seek to ensure that competitors less efficient than the undertaking with the dominant position should remain on the market.” See Intel v. Commission, Case C-413/14 P [2017] ECLI:EU:C:2017:632, §133. For an overview of possible ramifications of this case on the goals and scope of art. 102 TFEU, see NICOLAS PETIT, The Judgment of the EU Court of Justice in Intel and the Rule of Reason in Abuse of Dominance Cases 13-15 (2017), https://papers.ssrn.com/abstract=3086402 (last visited Dec 17, 2018).

${ }^{85}$ Svend Albæk, Consumer Welfare in EU Competition Policy, in AIMS AND VALUES IN COMPETITION LAW 67-88, 83 (Caroline Heide-Jørgensen et al. eds., 2013); Jan Sviták \& Jarig van Sinderen, Economic Impact of Competition Policy: A Look Beyond Consumer Surplus, 166 DE ECONOMIST 23-40 (2018).

${ }^{86}$ JONES AND SUFRIN, supra note 62 at 268.

${ }^{87}$ See, for instance, Décision du 23 janvier 2012 relative à des pratiques mises en œuvre dans le secteur de la fourniture d'informations météorologiques aux professionnels, 12-D-04 [2012], English press release available at:

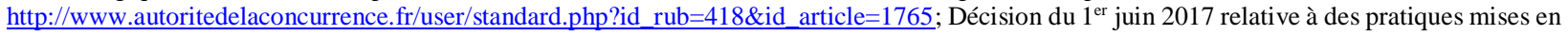
oeuvre par l'Institut national de recherches archéologiques préventives dans le secteur de l'archéologie préventive, 17-D-09 [2017], English press release available at: http://www.autoritedelaconcurrence.fr/user/avisdec.php?lang=fr\&numero=17-D-09
} 
As the legality principle requires government activity to be prescribed by law, it is likely for commercial divisions of public entities to perform their commercial activities on the basis of a statutory or administrative provision. ${ }^{88}$ For instance, the Netherlands Chamber of Commerce, a government agency, performs a number of commercial activities premised on a statutory provision allowing it to initiate non-essential services alongside its statutory tasks ${ }^{89}$ Moreover, legislative provisions may be in effect that regulate the behavior of commercial divisions of public entities, for instance related to pricing. Some Member States have sectoral provisions to this end, ${ }^{90}$ while others, such as the Netherlands, require this on a blanket ex-ante basis. ${ }^{91}$ Such legal bases for commercial activities, however, could lead to a conflict between regulation and competition law that competition authorities have a hard time to resolve.

Consider the example of a commercial division of a public entity that is required by law to sell its products or services at least at marginal cost. As the state of perfect (Bertrand) competition in which price is equal to marginal cost is quite rare in real markets, ${ }^{92}$ pricing at marginal costs by the commercial division could drive private competitors out of the market. A competition authority could open proceedings, establish predatory pricing, and issue commitment decisions or fines in such a case. ${ }^{93}$ The institutional problem here is that the competition authority will only be able to address individual anticompetitive conduct and not the overarching law allowing this conduct.

Regulation that enables anticompetitive behavior generally typically cannot be voided by a competition authority, leading to inefficient ex post enforcement on a case-by-case basis. ${ }^{94}$ Granted, regulation that enables anticompetitive conduct in some Member States, such as Italy, Spain and Sweden could be challenged by a competition authority before court, ${ }^{95}$ which would allow the legislation in question to ultimately be voided by a constitutional court. Proceedings leading to voidance of laws before constitutional courts - generally courts of last resort - tend to take several years. In the meantime, private competitors may already have been driven out of the market entirely.

Alternatively, it should be noted, the European Commission or private litigants could challenge legislation allowing for anticompetitive conduct by commercial divisions of public entities by relying on art. 106(1) in conjunction with 102 TFEU. Art. 106(1) applies to (public) undertakings or undertakings that are granted exclusive rights, concerning which Member States may not enact legislation contrary to the TFEU, particularly the competition policy of art. 101109 TFEU. ${ }^{96}$ When a commercial division of a public entity would qualify as a (public) undertaking, ${ }^{97}$ the substantive application of 106(1) would be relevant when "a measure imputable to a Member State gives rise to a risk of an abuse of a dominant position. ${ }^{98}$ In such cases, private or commission enforcement could indeed provide an alternative route towards voidance of legal provisions that allow anticompetitive conduct by commercial divisions of public entities.

\section{Behavioral constraints}

Besides the institutional constraints, competition authorities can also be faced with behavioral constraints during proceedings involving public entities. There may be various implicit or explicit factors that prevent a competition authority from acting neutrally vis-a-vis alleged violations of competition law by public entities.

A competition authority may prioritize private offenders over public offenders and could be more restrained in its treatment of alleged public offenders. There could be political or managerial pressure to treat alleged public offenders more leniently. Alternatively, a competition authority could be subject to internalized self-restraint out of a moral

${ }^{88}$ OECD, Inventory of Competitive Neutrality Distortions and Measures 12-13 (2015).

${ }^{89}$ See art. 30-31 Wet Kamer van Koophandel ("Chamber of Commerce Act"), BWBR0034331

${ }^{90}$ OECD, Summary of the discussion, 7 OECD JOURNAL OF COMPETITION LAW AND POLICY 286-304, 293 (2004).

${ }^{91}$ See art. 25 Mededingingswet (“Competition Act”), BWBR0008691

${ }^{92}$ In microeconomics, this situation is referred to as the 'Bertrand Paradox,' see, e.g. Martin Dufwenberg \& Uri Gneezy, Price competition and market concentration: an experimental study, 18 INTERNATIONAL JOURNAL OF INDUSTRIAL ORGANIZATION 7-22 (2000); Klaus Abbink \& Jordi Brandts, Price Competition Under Cost Uncertainty: A Laboratory Analysis, 43 ECONOMIC InQUIRY 636-648 (2005); Lisa V. Bruttel, Group dynamics in experimental studies-The Bertrand Paradox revisited, 69 JOURNAL OF ECONOMIC BEHAVIOR \& ORGANIZATION 51-63 (2009).

${ }_{93}$ More on this at section III-C-3 (the regulated conduct defense)

${ }^{94}$ OECD, supra note 18 at 5 .

${ }^{95}$ OECD, supra note 15 at 15-16; SWEDISH COMPETITION AUTHORITY, supra note 47.

${ }^{96}$ See, e.g. Régie des télégraphes et des téléphones v. GB-Inno-BM, Case 18/88 [1991], ECR 5941; Höfner, supra note 48; Elliniki Radiophonia Tiléorassi et al. v. Dimotiki Etairia Pliroforissis ERT, Case C-260/89 [1991] ECR I-5941; Merci convenzionali porto di Genova SpA v. Siderurgica Gabrielli SpA, Case C-179/90 [1991] ECR 5889

${ }^{97}$ See supra section III-A

${ }^{98}$ Commission v. DEI, Case C-553/12 P [2014] EU:C:2014:2083, §42. For background, see Damian Chalmers, Gareth Davies \& Giorgio Monti, State Regulation and EU Competition Law, in EUROPEAN UniOn LAW: CASES AND MATERIALS (2012); Kelyn Bacon, State Regulation of the Market and EC Competition Rules, 18 EUROPEAN COMPETITION LAW REVIEW 283-291 (1997). 
obligation not to turn on other civil servants, or out of fear for retaliation. Petit has demonstrated that such unequal treatment between alleged private and public competition law offenders can manifest during all stages of proceedings. ${ }^{99}$ Both in case selection, investigation, decisions and sanctioning the competition authority can be subject to the biases mentioned above that amount to preferential treatment of public entities.

To be clear: national competition authorities in the EU tend to be independent agencies on both a functional and a structural level, and this independence tends to be enshrined in law. EU competition authorities typically do not operate under direct control of politicians. ${ }^{100}$ At the same time, it has been pointed out that complete independence from government and politics is hard to achieve for agencies in general, and competition authorities in particular. ${ }^{101}$ Competition authorities' independence is vulnerable at certain "pressure points," such as the (political) appointment of commissioners, funding, and the legislative process on laws affecting competition authorities. ${ }^{102}$ Maintaining independence from government, therefore, may be hard enough in and of itself for competition authorities, let alone while at the same time investigating or sanctioning parts of government.

Enforcement against anticompetitive behavior by public entities, therefore, may point out a weak spot in the otherwise independent status of competition authorities. Even when there is a legislative framework in place controlling for anticompetitive behavior by public entities, the fact that public entities are the perpetrator makes enforcement less straightforward as compared to enforcement against private firms. ${ }^{103}$

In practice reports on actual public enforcement against anticompetitive behavior by public entities have been mixed. Most of the (few) countries in which a designated agency is in place to enforce against anticompetitive behavior by governments, report both a prevalence of undesirable behavior and a general lack of public enforcement thereof. ${ }^{104} \mathrm{At}$ the same time Spain reports a strong enforcement practice, with multiple cases having been adjudicated by the designated enforcement agency. ${ }^{105}$ At this point it is unclear which circumstances have led to the situation in which enforcement against for-profit government initiatives is present in some and absent in other countries.

\section{Regulated Conduct Defense}

As mentioned above, commercial divisions tend to perform their commercial tasks supported by statutory or regulatory provisions, possibly leading to conflicts between regulation and competition law. A legal basis for de facto anticompetitive conduct would however also allow the commercial division to invoke the 'regulated conduct defense' upon appeal before a court.

The regulated conduct defense has been established in both art. 101 and 102 TFEU case law. It stipulates that when law or regulation requires undertakings to behave in a way that is de facto anticompetitive, such behavior is not attributable to the undertaking itself. ${ }^{106}$ It should be noted, though, that the courts have defined the scope of a regulated conduct defense narrowly: the statutory or regulatory provision should leave the undertaking no other option but to act anticompetitively. ${ }^{107}$ Both approval by a regulatory authority of anticompetitive behavior to which the undertaking took initiative and (tacit) encouragement by a regulatory authority do not fall under the penumbra of the regulated conduct defense. ${ }^{108}$

\footnotetext{
${ }^{99}$ Nicolas Petit, Implications of Competitive Neutrality for Competition Agencies: A Process Perspective, SSRN ELECTRONIC JOURNAL (2015), http://www.ssrn.com/abstract=2620735 (last visited Jun 20, 2018).

${ }^{100}$ Stephen Wilks, Agencies, Networks, Discourses and the Trajectory of European Competition Enforcement, 3 EUROPEAN COMPETITION JOURNAL 437-464 (2007).

${ }^{101}$ See, e.g. Johan W. Van de Gronden \& Sybe A. De Vries, Independent competition authorities in the EU, 2 UTRECHT LAW REVIEW 32 (2006).

${ }_{102}$ William Kovacic, Competition agencies, independence, and the political process, in COMPETITION POLICY AND THE ECONOMIC APPROACH: Foundations AND Limitations 291-311 (Josef Drexl, Wolfgang Kerber, \& Rupprecht Podszun eds., 2011).

${ }^{103}$ Deborah Healey, Competitive Neutrality and the Role of Competition Authorities: A Glance at Experiences in Europe and Asia-Pacific, 7 REVISTA DE DEFESA DA CONCORRÊNCIA 51-68, 66 (2019).

104 LARS MEINDERT ET AL., Evaluatie Wet Markt en Overheid 2012-2015 (2015), https://www.rijksoverheid.nl/documenten/rapporten/2015/08/06/valuatie-wet-markt-en-overheid-2012-2015; AUSTRALIAN GOVERNMENT, Review of the Commonwealth Government's Competitive Neutrality Policy (2017), https://consult.treasury.gov.au/market-and-competition-policydivision/competitive-neutrality-review/supporting_documents/CN\%20Review\%20Consultation\%20Paper.pdf.

${ }^{105}$ Carlos Padrós Reig \& José María Macías Castaño, Los instrumentos administrativos de garantía de la unidad de mercado, REviSTA DE ADMINISTRACIÓN PÚBLICA 113-151 (2014).

${ }^{106}$ See, mainly, Commission and France v. LadbrokeRacing, Joined Cases C 359/95 P and C 379/95 P [1997] ECR I 6265, at § 33; Deutsche Telekom v. Commission, Case T-271/03 [2008], ECLI:EU:T:2008:101, at § 85-89

${ }^{107}$ Deutsche Telekom v. Commission, Case C-280/08 P [2010], ECLI:EU:C:2010:603, at $\$ 56$

${ }^{108}$ Deutsche Telekom, supra note 106, at $\$ 87$ and 117
} 
Commercial divisions of public entities could operate under a variety of legal provisions, yet it seems that anticompetitive conduct will generally be on the commercial divisions' own initiative. Consider, for instance, a branch of the national forestry service acting under a legal provision to sell biomass, and then deciding to lower prices to force out competitors. In this example the anticompetitive behavior takes place on the subsidiary's own initiative, and the regulated conduct defense will likely not be upheld by a court.

Things would be less clear-cut when, as mentioned above, the branch of the Forestry Service were required by law to sell its biomass at marginal cost. The commercial division has no other choice here but to price sub-competitively, effectively driving private competitors out of the market. In this scenario it seems more plausible for the regulated conduct defense to hold up in court: the branch of the Forestry Service did not take the initiative to set its prices at an anticompetitive level, but was required to do so by law.

\section{CONSEQUENCES FOR COMPETITION AND THE INTERNAL MARKET}

The previous sections have established (1) that commercial divisions of public entities are prevalent in the EU, and can have an appreciable negative effect on competition; (2) EU member states generally approach competitive behavior by public entities through a competition law framework, even though in many cases the commercial division would not qualify as an undertaking and thus fall outside of the scope of competition law; (3) under the circumstances in which EU competition law would apply, anticompetitive behavior of these commercial divisions would likely fall under the abuse of dominance regime; and (4) while abuse of dominance may be established on a substantive level, competition authorities face numerous procedural challenges when enforcing against commercial divisions of public entities.

This situation could be problematic on various levels, raising concerns about the effectiveness of competition law when commercial divisions of public entities are active on markets.

First of all, it is problematic that anticompetitive behavior by a commercial division would altogether fall outside the scope of competition law, when inseparable from a public entity's exercise of public power according to established case law. ${ }^{109}$ This situation creates an uneven playing field between public and private competitors, where competition law applies to only the latter and not to the former. Moreover, a public entity with a commercial division even could informally influence the legislative process of the (re)definition of its own statutory tasks, to make sure that its commercial activities are explicitly related to its exercise of public power.

Second, under the above circumstances commercial divisions could be subject to different competition law scrutiny across EU member states. Throughout the EU there are various competition law-related regimes applicable to commercial divisions of public entities. France and the UK, for instance, rely on generic competition law. Sweden, Finland, Denmark and the Netherlands have added on specific, competition law-inspired, legal provisions for anticompetitive behavior by public entities. This situation could be problematic for private firms active in multiple Member States, where they face multiple public competitors.

For example, a firm offering meteorological services throughout the EU will face competition from commercial divisions of National Meteorological Institutes in multiple Member States and will have to compete with these public competitors under various competition law-related regimes. In some Member States, the meteorology firm will face a public competitor required to price at marginal cost, while in others so such requirements exist. In some Member States the meteorology firm could lodge a complaint before the competition authority, while in others it will have to go to a court directly. For the private competitor, this leads to different levels of the playing field across Member States, both in substantive and procedural application of competition law-inspired frameworks. This differentiation of competition law increases transaction costs for private firms and could impose entry barriers to certain European markets-which would fragment the internal market for various goods and services on which commercial divisions of public entities are active.

It seems plausible, moreover, that the first and second problematic consequences outlined above are related. Because legislators in various Member States, such as the Netherlands, Denmark, Sweden and Finland may have deemed EU competition law ill-equipped to adequately address anticompetitive behavior by public entities, they have enacted additional legislation on top of EU competition law. This, however, may have led to a fragmentation of the legal

\footnotetext{
${ }^{109}$ Supra footnotes 55-57
} 
framework for firms competing with public entities across the EU, and could even affect the competitive playing field itself.

Third, In all Member States, private competitors of commercial division of public entities may experience negative consequences from the procedural constraints outlined above. ${ }^{110}$ Irrespective of the application of competition law provisions, private competitors could be disadvantaged by conflicting regulatory and competition law provisions and by implicit or explicit biases of competition authorities. Even when private firms are able to challenge anticompetitive behavior by competing commercial divisions of public entities, they would face procedural disadvantages before competition authorities and courts.

\section{A. Possible remedies}

Commercial divisions of public entities thus both complicate the application of competition law on a substantive and procedural level, and can have a fragmenting effect on the internal market because of the various competition lawrelated regimes that apply across the EU. In what follows, remedies for some of these challenges are discussed.

\section{Competition Law Harmonization}

Harmonization could relate to both substantive EU competition law and the enforcement thereof. The substantial application of EU competition is considered to be highly harmonized across Member States, while because of the various legal systems in the EU there is more divergence in enforcement. ${ }^{111}$ Harmonization could remedy two challenges outlined above.

First, the variety of competition law related regimes with respect to commercial divisions of public entities seems to be caused by addenda to EU competition law provisions that some Member States have enacted. Sweden, Finland, Denmark and the Netherlands for instance have instantiated additional competition law provisions pertaining to public competitors on markets. Other Member States, such as France and the UK, rely on generic application of art. 102 when approaching commercial divisions of public entities. As outlined above, this divergence of legal regimes can lead to increased transaction costs for firms and to entry barriers.

As of yet it is unclear which of the various competition law-related regimes works optimally as regards to commercial divisions. If an optimal approach could be determined, this approach could be harmonized on an EU level by Commission guidelines, an EU legal instrument or even an amendment to the TFEU. There is precedent for such harmonization of competition law, for instance relating to the SGEI. ${ }^{12}$ While the application of competition law to SGEI has been part of the EU treaties since the founding of the Treaty of Rome, the concept of SGEI has been further defined by article 14 TFEU, protocol 29 and article 36 of the European Charter. The Commission has taken considerable effort to harmonize the application of competition law to SGEI through non-legislative guidelines. ${ }^{113}$

At the same time, it is unclear whether it is practically feasible to determine an optimal EU-wide competition law approach to commercial divisions of public entities to begin with. While many EU countries have reported issues related to anticompetitive behavior by commercial divisions of public entities, ${ }^{114}$ market structures, administrative law frameworks and applicable sector-specific regulation can differ widely across Member States. Even when an optimal substantive approach could be determined, autonomous factors across Member States can complicate the practical viability of such harmonization.

Second, harmonization could play a role regarding the behavioral constraints that competition authorities face when dealing with alleged public offenders of competition law. In fact, the European Commission has proposed a Directive to, amongst others, strengthen the independence of Member States' competition authorities. ${ }^{115}$ While this directive does not specifically address competition authorities' enforcement regarding public entities, it does recognize and address behavioral and institutional constraints to National competition authorities' independence. Amongst others,

\footnotetext{
${ }^{110}$ Supra section III-C

${ }^{111}$ Bogdan M. Chiriţoiu, Convergence Within the European Competition Network: Legislative Harmonization and Enforcement Priorities, in THE CONSISTENT APplication of EU Competition LAW: Substantive ANd Procedural Challenges 3-22 (Adriana Almășan \& Peter Whelan eds., 2017).

${ }^{112}$ Supra section III-A

${ }^{113}$ See Communication from the Commission, supra note 61

${ }^{114}$ OECD, supra note 90.

${ }^{115}$ Proposal for a Directive of the European Parliament and of the Council to empower the competition authorities of the Member States to be more effective enforcers and to ensure the proper functioning of the internal market [2017] COM(2017) 142 final, 2017/0063 (COD)
} 
the directive strengthens independence from political or external influence, ${ }^{116}$ harmonizes the reach of investigative and remedial powers, ${ }^{117}$ and cements the position of competition authorities before national courts. ${ }^{118}$ It is an open question, however, whether these measures will have an actual effect on the behavioral restraints that competition authorities seem to experience when enforcing against public entities. Stronger codified safeguards may contribute to more independent enforcement practices, but institutional structures outside of competition law will remain.

Harmonization may thus counter the negative effects of various competition law-related regimes concerning public commercial divisions and mitigate behavioral constraints of national competition authorities. At the same time, it should be pointed out that harmonization will not be able to address possible conflicts between regulation and competition law. ${ }^{119}$ Moreover, harmonization as a recommendation may only be attractive on a theoretical level, as there are too many practical factors hindering effective harmonization in the markets and legislative frameworks of the Member States. ${ }^{120}$

Finally, harmonization of competition law assumes that competition law is at least part of the solution to mitigate anticompetitive behavior by commercial subsidiaries of public entities. Given the issues with the substantive application of competition law towards commercial divisions, ${ }^{121}$ it is debatable if harmonization of competition law would be the appropriate way forward.

\section{Regulatory harmonization beyond competition law}

Competition law may be, at best, limited in its application to anticompetitive behavior by commercial divisions of public entities. In many cases the commercial division will not qualify as an undertaking under competition law. If, then, a commercial division would substantively be found to abuse its dominance, its private competitors face a number of procedural disadvantages.

Besides harmonization of competition law, another remedy could lie outside the realm of competition law altogether. Indeed, among the many OECD recommendations to level the playing field between public and private competitors only few relate to competition law principles. ${ }^{122}$ While distortions of competition by public entities are mainly addressed through competition law in OECD countries, ${ }^{123}$ the OECD rather recommends a standalone regulatory framework overseen by a designated enforcement agency. ${ }^{124}$ The only OECD country that acts according to this recommendation is Australia, which has had codified principles of 'competitive neutrality' starting in the 1990s and has instantiated a complaints office with investigative (though no enforcement) powers. ${ }^{125}$

Similar efforts within the EU would in all likelihood be inefficient on a Member State level, as differences between regulatory frameworks of individual Member States would fail to create conditions that would satisfy internal market goals. A harmonized regulatory framework could address all matters of competition between public and private actors on markets, including anticompetitive behavior by commercial divisions of public entities. Such a framework could incorporate a level playing field between public and private competitors on a level of costs structure, structural separation, the limits of public service obligations, as well as equality conditions in taxation, credit and debt, public procurement and enforcement. Given the current state of EU harmonization on some of these conditions, notably taxation, such harmonization does not seem viable in the short term, however.

\section{CONCLUSION}

This article has been explorative in nature. It has established commercial divisions of public entities as a relatively new and little-studied phenomenon, and pointed towards possible motivations for commercial divisions to compete

\footnotetext{
${ }^{116}$ Proposal for Directive, $i d$, art. 4-5

${ }^{117} I d$. , art. 6-11; 12-15

${ }^{118} I d$., art. 28

${ }^{119}$ Supra section III-C-1

${ }^{120}$ For a critical assessment on the feasibility of harmonization, see Paul B. Stephan, Global Governance, Antitrust, and the Limits of International Cooperation, CORNELl INTERNATIONAL LAW JOURNAL 173-218 (2005); For a more optimist view on the feasibility of harmonization, see Diane P. Wood, International Harmonization of Antitrust Law: The Tortoise or the Hare, CHICAGo Journal OF INTERNATIONAL LAW 391-408 (2002).

${ }^{121}$ See supra section III-A

${ }^{122}$ See OECD, supra note 3 at 23-24: separating commercial and public activities; identifying and separating direct costs of commercial activities; achieving commercial rates of return; defining size and scope of public service obligations; establish tax equality; establish regulatory neutrality; establish debt neutrality; establish neutral public procurement.

${ }^{123}$ Supra note 26

${ }^{124}$ OECD, supra note 3 at 88.

${ }^{125} \mathrm{OECD}$, supra note 18 at 17
} 
on markets. These motivations concern internal purposes; mainly the intention to balance budgets after cuts by the central government, or external purposes to raise revenue at the request of the central government.

Furthermore, the paper has outlined possible distortions of competition by commercial divisions. These distortions concern hampering entry to markets by private competitors and driving existing private competitors out of the market. They follow from advantages in regulation, taxation, information and general cross-subsidies.

Next, the article outlined how anticompetitive practices by public entities are generally approached through competition law(-inspired) frameworks in the EU, and explored to what extent competition law would be suitable to address these practices.

As it turns out, competition law is limited in its approach to anticompetitive practices by commercial divisions of public entities. When connected to the parent organization's exercise of public power, a commercial division will most likely not be considered an undertaking and would fall outside of the scope of competition law altogether. If the public entity's commercial activities are sufficiently separate from the organization's exercise of public power according to doctrine, the abuse of dominance regime could be applied to the commercial division. Negative effects on consumer welfare could be recognized related to (for instance) predatory pricing, refusal to supply or margin squeeze. Naturally dominance would have to be established before such abuse would be considered unlawful.

While abuse of dominance could thus be established on a substantive level for those commercial divisions that qualify as an undertaking, private competitors could face procedural disadvantages in the subsequent investigation and enforcement. These disadvantages follow from institutional constraints (competition authorities generally cannot void laws enabling anticompetitive practices by commercial divisions), behavioral constraints when a competition authority enforces against a public entity, and from the regulated conduct defense invoked by the commercial division.

Finally, this article has outlined problematic consequences of the apparent limits of EU competition law to tackle anticompetitive conduct by commercial divisions of public entities. First, an unequal playing field follows from the different treatment of private and public competitors in the application and enforcement of competition law. Second, the various competition law-inspired approaches towards commercial divisions across the EU hamper the internal market. The article concludes by suggesting possible remedies to these consequences: harmonization of competition law relating to anticompetitive behavior by commercial divisions, or enacting a standalone regulatory framework beyond competition law.

The austerity measures after the global financial crisis that seem to have incentivized public entities to raise additional revenue through commercial divisions are up to ten years behind us. Even in the current period of near-global economic growth, commercial divisions of public entities remain active on markets. This suggests that the phenomenon is here to stay.

The findings of this research suggest that the existing legal framework has a hard time catching commercial divisions of public entities; as a concept it seems to elude traditional legal demarcations. Their commercial, revenue-driven focus over public interest objectives and presence on otherwise private markets leads beyond the framework of art. 106 (1) and (2) TFEU, which was instantiated to cover market activities by public sector actors. At the same time, commercial divisions' activities on markets can be similar enough to the public organization's exercise of public power, ${ }^{126}$ so that competition law does may not apply either.

Given the (potentially) negative effects of commercial divisions on markets and the rule of law, and the apparent ineffectiveness of the existing legal framework, it is relevant to pursue follow-up research on the topic. Such further research could focus on a number of aspects:

First, the effect of commercial divisions on market structure and performance has only been studied theoretically, and evidence of distortion of competition by commercial divisions is largely anecdotal. Further empirical and experimental research would be appropriate in order to better establish the actual and potential distortion of competition by commercial divisions.

\footnotetext{
${ }^{126}$ Supra notes 55-57
} 
Second, more thorough comparative legal research has to be conducted to definitively map the prevalence of commercial divisions of public entities in the EU, and outline the different legal regimes across the EU and beyond pertaining to these commercial divisions. Such comparative legal research would allow for best-practice examples of regulatory responses.

Third, the welfare effects of anticompetitive behavior by public commercial divisions need to be studied more elaborately in relation to the abuse of dominance doctrine. At this point it is unclear how welfare enhancing price effects relate to welfare decreasing effects on quality and consumer choice in case of alleged abuse of dominance by a commercial division. Such scholarship in competition law could inform future enforcement or litigation endeavors.

Fourth, it would be worthwhile to branch out from competition law to competition policy, and investigate how commercial divisions of public entities relate to state-aid law. Like in competition law, a literature has developed on the application of state-aid law and SOEs, ${ }^{127}$ but not so much on commercial divisions.

Fifth, beyond the realm of competition or even economic law, it would be appropriate to further explore the ramifications on general rule of law principles of anticompetitive behavior by commercial divisions. These practices could blur boundaries between the state and the private sector, and introduce revenue streams financing political corruption and cronyism. Further study related to constitutional and administrative law could shed light on these issues more substantially.

\footnotetext{
${ }^{127}$ See, e.g. Friederiszick and Kałużny, supra note 14; Thomas Jaeger, Distinguishing state and private subsidies: a closer look at the state character test, in STATE-INITIATED RESTRAINTS OF COMPETITION 296-312 (Josef Drexl ed., 2015).
} 